\section{Nauplius}

THE JOURNAL OF The Brazilian Crustacean Society

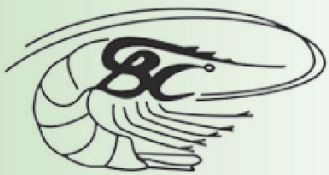

e-ISSN 2358-2936

www.scielo.br/nau www.crustacea.org.br

\title{
Population dynamics of a freshwater amphipod from South America (Crustacea, Amphipoda, Hyalellidae)
}

\author{
Daniela da Silva Castiglioni ${ }^{1,2}$, Aline Vasum Ozga ${ }^{2}$, Stella \\ Gomes Rodrigues ${ }^{3}$ and Alessandra Angélica de Pádua Bueno ${ }^{3}$
}
1 Laboratório de Zoologia e Ecologia, Campus de Palmeira das Missões, Universidade Federal de Santa Maria. Avenida Independência, 3751. 98300-000 Palmeira das Missões, Rio Grande do Sul, Brazil.

2 Programa de Pós-Graduação em Biodiversidade Animal, Centro de Ciências Naturais e Exatas, Universidade Federal de Santa Maria, Prédio 17, Sala 1140-D, Cidade Universitária, Camobi, Km 9. 97105-900 Santa Maria, Rio Grande do Sul, Brazil.

3 Departamento de Biologia, Programa de Pós-Graduação em Ecologia Aplicada, Universidade Federal de Lavras, Campus Universitário, 37200-000 Lavras, Minas Gerais, Brazil.

ZOOBANK http://zoobank.org/urn:lsid:zoobank.org:pub:E8BF9D91-73C7-41EDBACC-5E76B386C0C8

\section{ABSTRACT}

This study aimed to characterize the population dynamics of Hyalella bonariensis Bond-Buckup, Araujo \& Santos, 2008 from headwater spring in a rural area of state of Rio Grande do Sul, Brazil. Four samples were collected in August (winter) and October (spring) of 2012 and January (summer) and April (autumn) of 2013. Ovigerous females and precopula pairs were separated from other individual in the field. A total of 5,266 specimens were sampled, being 1,878 males, 2,073 females (including 240 ovigerous females) and 1,315 juveniles. The frequency distribution of size classes (measured as cephalothorax length, CL) was polymodal and bimodal in males and females, respectively. Males reach larger size than females. Sexual maturity of males and females was estimated at 0.40 and $0.38 \mathrm{~mm}$ for $\mathrm{CL}$, respectively. Total sex ratio favored females, and these were more frequent in intermediate size classes, while males were more frequent in larger size classes. Ovigerous females and couples were found in four seasons, but both were more abundant in winter. Juveniles were also found in all seasons, being more frequent in winter and spring. These results showed that this H. bonariensis population has similar dynamics to other species of Hyalella Smith, 1874 from Brazil, but present variations when compared to other freshwater amphipods.

CORRESPONDING AUTHOR Daniela da Silva Castigloni danielacastiglioni@yahoo.com.br

SUBMITTED 12 December 2015 ACCEPTED 30 August 2016 PUBLISHED 12 December 2016

\section{KEY WORDS}

Body size, Hyalella, reproductive period, sex ratio, sexual maturity. 


\section{INTRODUCTION}

The conservation of an ecosystem depends on knowledge of ecological aspects of its populations. The study of the abundance and size of a population, its stability, productivity, role in the food chain, reproductive period, recruitment, average lifetime, emigration and immigration rates, among other aspects, are crucial for long-term conservation plans (Cooper, 1965; Hutchinson, 1981; Muskó, 1992). All the information about population dynamics of a species support and guide the creation of conservation programs, the evaluation of its extinction risk and sustainable use, as well as its potential use in bioindication and ecotoxicological studies (Brawn and Robinson, 1996).

The crustaceans of the genus Hyalella Smith, 1874 have a great ecological importance, as they provide energy transfer between different trophic levels, convert detritus into fine particulate organic matter and serve as food for many waterfowl, fish and invertebrates (Swanson, 1984; Wen, 1992; Wellborn, 2002; Wellborn and Cothran, 2007). Besides, Hyalella are organisms most commonly used in environmental quality tests in temperate climates mainly due to their high sensitivity to contaminants and environmental impacts (Duan et al., 1997; Rinderhagen et al., 2000; Neuparth et al., 2002; Morris et al., 2003; Wilcoxen et al., 2003; Gust, 2006; Ding et al., 2011).

The genus Hyalella comprises species of amphipod crustaceans that occur in freshwater ecosystems and have distribution restricted to Americas (Bento and Buckup, 1999). Among the 66 described species, 23 are found in Brazil and of these, nine species occur in the southernmost state, Rio Grande do Sul, region with the highest diversity of the genus in the country (Bueno et al., 2014; Marrón-Becerra et al., 2014; Rodrigues et al., 2014; Colla and César, 2015). Among the species that occur in Brazil, Hyalella bonariensis Bond-Buckup, Araujo \& Santos, 2008 has a wide geographical distribution, occurring in Argentina and also in 13 wetlands in the state of Rio Grande do Sul (Bueno et al., 2014). However, its biology and ecology are still unknown. Regarding the biology of native species of Hyalella from Brazil, studies have been conducted about ecology and reproduction of two sympatric species, Hyalella pleoacuta González, Bond-Buckup and Araujo, 2006 and Hyalella castroi González, Bond-Buckup and
Araujo, 2006 (Castiglioni and Bond-Buckup, 2007; 2008a; 2008b; 2009; Castiglioni et al., 2007).

Thus, this study aimed to characterize the population dynamics of the freshwater amphipod $H$. bonariensis from southern Brazil, and for this the frequency distribution, body size, sexual maturity, sex ratio, reproductive period and recruitment were analyzed. These biological aspects can be used to create conservation and ecotoxicology programs for freshwater aquatic environments in Brazil.

\section{Material and Methods}

Specimens of the H. bonariensis population were sampled in August (winter) and October (spring) of 2012 and January (summer) and April (autumn) of 2013, from a headwater spring in a rural area called

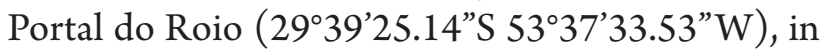
Silveira Martins municipality, central region of state of Rio Grande do Sul, southern Brazil. The samples were performed by only one person, with the aid of a hand net (mesh of $250 \mu \mathrm{m}$ ) for 20 minutes.

Ovigerous females and pre-copula pairs were separated from other individual in the field and preserved (70\% ethanol) in microtubes, and the other specimens were taken to the laboratory, sorted and preserved in $70 \%$ ethanol. Later, specimens were identified and the cephalothorax (i.e. head) length (CL, in $\mathrm{mm}$ ) was measured using a micrometer eyepiece in a stereoscopic microscope.

Specimens were classified into four categories: juveniles (individuals lacking secondary sexual characteristics), males (individuals with the second pair of gnathopods well developed, larger than first pair), females (individuals with marsupium developed and a small second pair of gnathopods, subequal in size as the first pair) and ovigerous females (females carrying eggs or juveniles inside the marsupium) (Borowsky, 1991; Castiglioni and Bond-Buckup, 2008a).

The total frequency distribution in size classes was estimated in relation to $\mathrm{CL}$ of males and females (including ovigerous females). For each category, the width of the size classes was determined using the value of $1 / 4$ of the standard deviation from the mean values of cephalothorax (Markus, 1971). Normality of the frequency distributions was analyzed using ShapiroWilk test $(\alpha=0.05)$ (Zar, 1996). 
Minimum, maximum and mean cephalothorax lengths were estimated for males and females (including both ovigerous and non-ovigerous females). Size was compared among sexes using t-test $(\alpha=0.05)$ (Zar, 1996).

Size at the sexual maturity was estimated for both sexes based on the size of the smallest male and the smallest female found forming couples in pre-copula (Castiglioni and Bond-Buckup, 2008b; Wellborn et al., 2005).

Sex ratio was estimated as the total number of males divided by the total number of females (includes both ovigerous and non-ovigerous females) sampled. Besides, sex ratio was calculated by season and size classes (using CL). Later, the goodness of fit test (chisquare) was used to verify that the ratio found for sexual $H$. bonariensis follows the ratio of 1:1 (males: females) (Zar, 1996).

To estimate the reproductive period, we calculated the frequency of females that were ovigerous in relation of adult females. All females that were as large as or larger than the smallest female found in pre-copula (i.e. estimated size at sexual maturity) were included in this analysis. Then, the proportion of ovigerous females was compared between seasons using multinomial proportion test (MANAP; $\alpha=0.05$ ) (Curi and Moraes, 1981). We also calculated the relative frequency (\%) of pairs in precopulatory behavior and then compared between seasons using multinomial proportion test (MANAP; $\alpha=0.05$ ) (Curi and Moraes, 1981).

To evaluate the recruitment period (juveniles entry in population), we calculated the juvenile proportion in relation to adults for each season and we used a ChiSquare goodness of fit test (Chi-Square, $\chi 2)(\alpha=0.05)$ (Zar, 1996), in order to check if the proportion follows the pattern 1:1 ratio (juveniles: adults). We considered juveniles the specimens with CL smaller than $0.3 \mathrm{~mm}$, i.e., those individuals where the enlargement of the second pair of gnathopods could not be observed (male diagnostic characteristic) and the presence of a marsupium (female diagnostic characteristic) (Borowsky, 1991). Subsequently, we estimated the juvenile relative frequency by season and compared using multinomial proportion test (MANAP) $(\alpha=0.05)$ (Curi and Moraes, 1981).

All statistical analyses were performed using the software Statistica 7.0.

\section{RESULTS}

A total of 5,266 individuals were collected: 1,878 males, 2,073 females (including 240 ovigerous females) and 1,315 juveniles. Table 1 presents the number of males, females, ovigerous females and juveniles sampled in each season.

The frequency distribution in size classes of CL of males and females was not considered normal (males $\mathrm{W}=0.95$; females $\mathrm{W}=0.92 ; \mathrm{p}<0.05)$. Besides, frequency distribution of males and females was polymodal and bimodal, respectively (Fig. 1).

The CL of males of $H$. bonariensis ranged from 0.30 to $0.92 \mathrm{~mm}$ and that of females from 0.30 to $0.74 \mathrm{~mm}$. CL of males $(0.49 \pm 0.11 \mathrm{~mm})$ was significantly larger than females $(0.46 \pm 0.08 \mathrm{~mm})(t=9.80 ; \mathrm{p}<0.05)$. Sexual maturity of males and females was estimated at 0.40 and $0.38 \mathrm{~mm}$ for CL, respectively.

Sex ratio favored females (0.91 male: 1 female) $(\chi 2=9.62 ; \mathrm{p}<0.05)$, which were more frequent in all seasons, except in summer when males were more abundant $(\mathrm{p}<0.05)$ (Tab. 1$)$. For the sex ratio analysis by size classes of CL, females predominated in intermediate classes and males predominated in larger size classes ( $p<0.05$; Fig. 2).

Ovigerous females were sampled in all seasons, but in greater abundance in the winter $(65.4 \%$ of females were ovigerous) $(\mathrm{p}<0.05)$ (Fig. 3). Couples in pre-copula also occurred in all seasons, being more frequently collected in the winter $(\mathrm{p}<0.05)$ (Fig. 3 ).

Juveniles were found in all seasons, being more abundant in winter and spring (MANAP; $<<0.05$ ) (Fig. 4). They represented only $25 \%$ of the total sampled population, in a way that the adult specimens were more abundant in summer $(80.82 \% ; \chi 2=691.69$; $\mathrm{p}<0.05)$, autumn $\left(84.9 \% ; \chi^{2}=364.28 ; \mathrm{p}<0.05\right)$ and winter (76.64\%; $\left.\chi^{2}=531.27 ; \mathrm{p}<0.05\right)$.

\section{Discussion}

For frequency distribution in size classes in amphipods, bimodality and polymodality are apparently the most common distributions, and could be the result of a reduced growth rate in immature stage, juvenile recruitment pulses, migration, mortality or a differential distribution (Díaz and Conde, 1989). This pattern was observed in the population of $H$. bonariensis that showed a bimodal and polymodal distribution for females and males, respectively. This result may indicate that this population has reproduction peaks, with a 
Table 1. Number of males, females, ovigerous females, juveniles and total specimens of Hyalella bonariensis, sex ratio (males: females) and results of the $\chi^{2}$ test by sampling seasonal in Silveira Martins, state of Rio Grande do Sul, Brazil.

\begin{tabular}{lcccccc}
\hline & Males & $\begin{array}{c}\text { Females } \\
\text { (ovigerous females) }\end{array}$ & Juveniles & Total & M: F & $\chi^{2}$ \\
\hline Summer & 1,018 & $453(23)$ & 349 & 1,820 & $2.25: 1$ & $217.01^{*}$ \\
Autumn & 292 & $343(34)$ & 113 & 748 & $0.85: 1$ & $4.10^{*}$ \\
Winter & 424 & $1010(157)$ & 437 & 1,871 & $0.42: 1$ & $239.47^{*}$ \\
Spring & 144 & $267(26)$ & 416 & 827 & $0.54: 1$ & $36.81^{*}$ \\
Total & 1,878 & $2,073(240)$ & 1,315 & 5,266 & $0.91: 1$ & $9.62^{*}$ \\
\hline
\end{tabular}

Note.: “*” indicate significant difference in sex ratio $(\mathrm{p}<0.05)$.

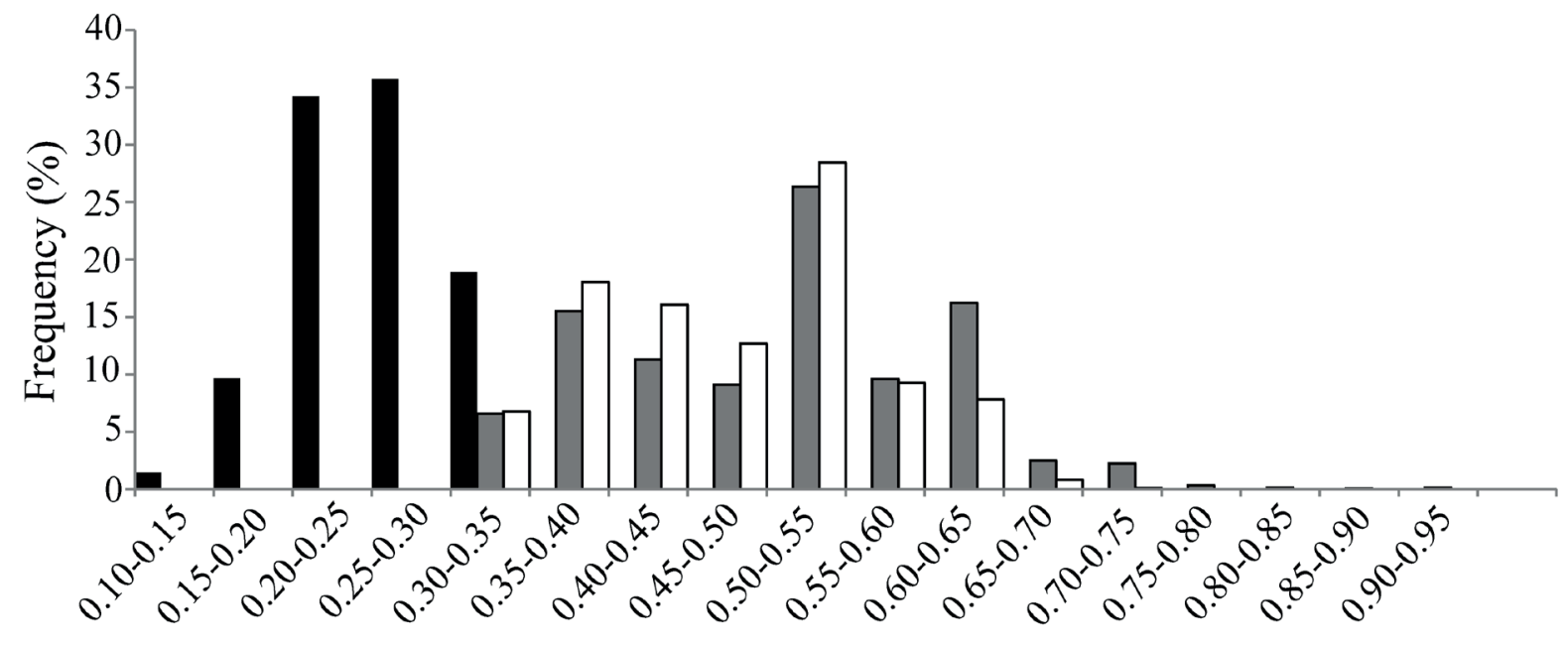

\section{Size Classes (mm)}

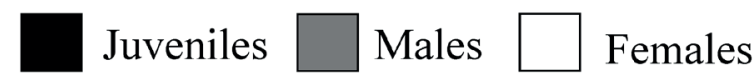

Figure 1. Frequency distribution in size classes of cephalothorax length (CL in $\mathrm{mm}$ ) for males and females from a population of Hyalella bonariensis of Silveira Martins, state of Rio Grande do Sul, Brazil.

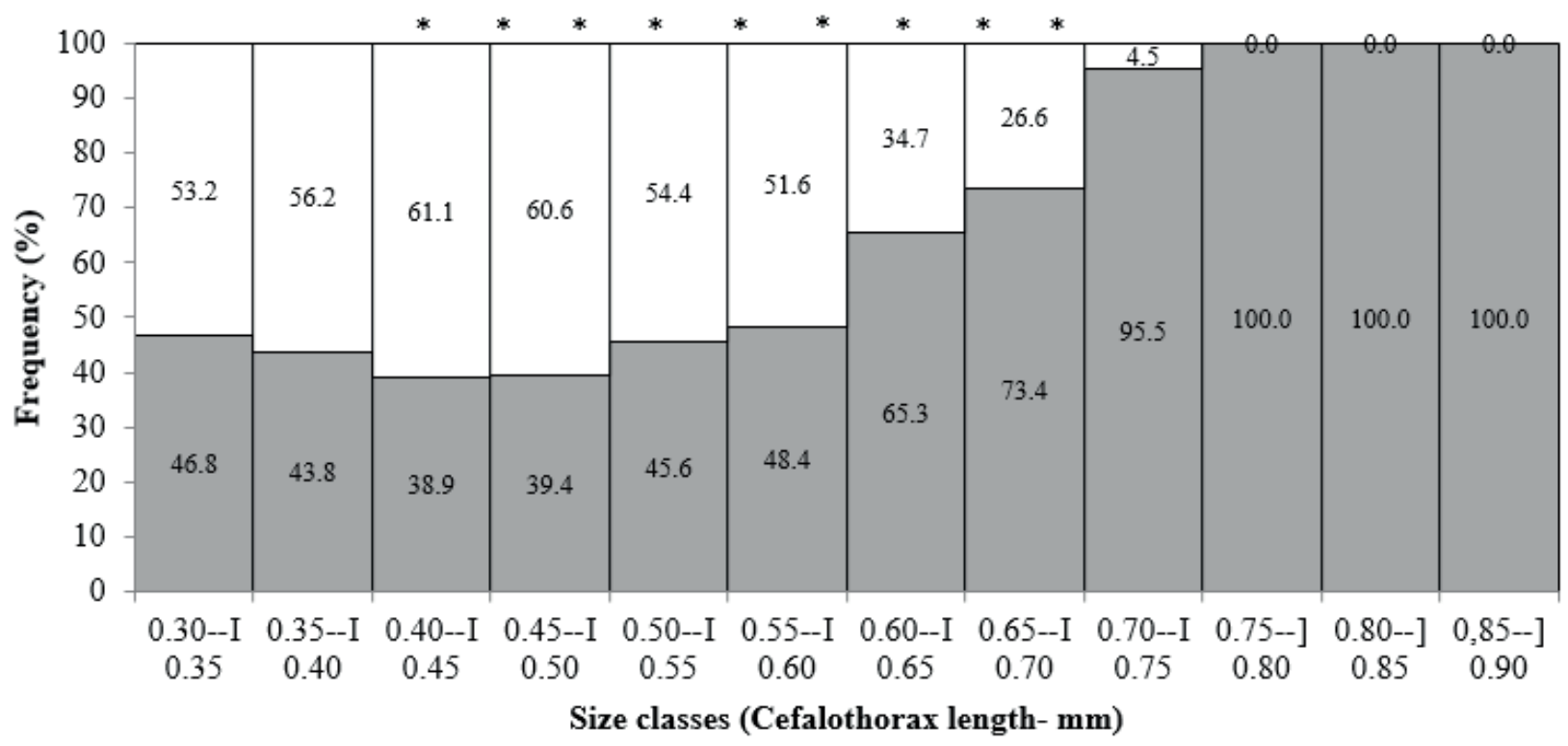

$\square$ Males $\square$ Females

Figure 2. Sex ratio of Hyalella bonariensis by size classes of cephalothorax length (CL in mm), from Silveira Martins, state of Rio Grande do Sul, Brazil. “*” indicate significant difference in sex ratio $(\mathrm{p}<0.05)$. 


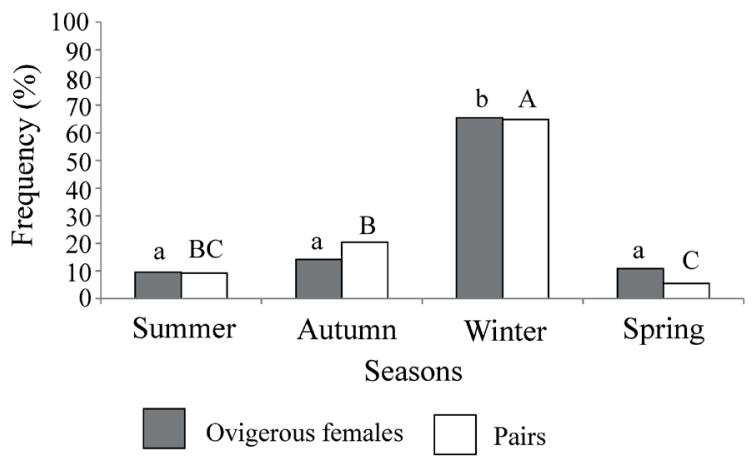

Figure 3. Relative frequency (\%) of ovigerous females and couples in pre-copula of Hyalella bonariensis from Silveira Martins, state of Rio Grande do Sul, Brazil. Lower case letters indicate the comparison of ovigerous females frequency between seasons and capital letters compare the frequency of the couples. Columns with at least one letter in common are not significantly different $(\mathrm{p}>0.05)$.

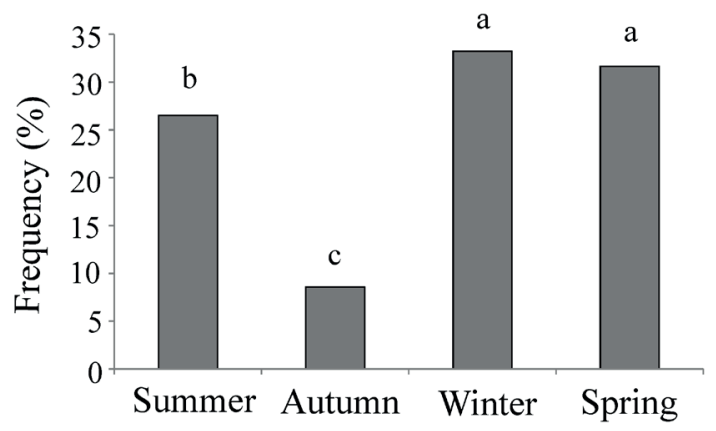

Seasons

Figure 4. Relative frequency (\%) of juveniles of Hyalella bonariensis from Silveira Martins, state of Rio Grande do Sul, Brazil. Columns with at least one letter in common are not significantly different $(\mathrm{p}>0.05)$.

consequent input of juveniles throughout the year. Besides, this assumption can be supported by the fact that juveniles and pre-copula pairs were found in all seasons.

These types of distribution have already been observed for other species of Hyalella, such as $H$. pleocuta, H. castroi (Castiglioni and Bond-Buckup, 2008b) and H. azteca (Saussure, 1858) (Pickard and Benke, 1996). For other amphipods, bimodal distribution also appears to be common as, for example, in Corophium multisetosum Stock, 1952 (Cunha et al., 2000), Echinogammarus longisetosus Pinkster, 1973 (Guerao, 2003), Talorchestia brito Stebbing, 1891 (Gonçalves et al., 2003) and Gammarus chevreuxi Seston, 1913 (Subida et al., 2005).
In crustaceans, it is well documented that generally males reach larger sizes than females, especially in freshwater amphipods as, for example, in H. pleocuta, $H$. castroi (see Castiglioni and Bond-Buckup, 2008b), $H$. azteca (see Pickard and Benke, 1996), Gammarus pulex (Linnaeus, 1758) (Adams and Greenwood, 1983), Gammarus leopoliensis Jadzewski \& Konopacka, 1989 (Zielinski, 1998) and E. longisetosus (see Guerao, 2003). According to Low (1978), males and females have similar growth rates until they reach sexual maturity, and then, later, they develop different reproductive and ecological demands, resulting in different growth rates. Thus, males invest energy in body growth, while females need to divide their energy between growth and reproduction, resulting in more prolonged intermolt periods and a minor increase in body size (Hartnoll, 1982; Borowsky, 1991; Wen, 1992; Thiel, 1999).

In addition, it is noteworthy that in some amphipods, including Hyalella, there is a pre-copula behavior in which males carry females for a few days before the copula occurs (Strong, 1972; Wellborn, 1995). So, the fact that males are larger than females enables them to carry females in an easily way (Adams and Greenwood, 1983; Adams et al., 1985). Furthermore, larger males may present a higher pairing success, once females prefer these individuals (Castiglioni and BondBuckup, 2008a). The population analyzed in this paper follows this pattern, in order that sexual dimorphism in relation to body size was observed, with males larger than females.

Sex ratio, along with the assessment of body size and distribution in size classes, is a population parameter estimated for several crustaceans. All parameters evaluated by such analyses have a direct influence on the population dynamics, especially in reproductive potential (Emmerson, 1994), which highlights the importance of being studied.

Females were more frequent than males, a result also observed for H. pleoacuta, H. castroi (see Castiglioni and Bond-Buckup, 2008b) and other amphipods (Powell and Moore, 1991; Cardoso and Veloso, 1996; Appadoo and Myers, 2004; Kevrekidis, 2004; 2005). Deviations observed in sex ratio of $H$. bonariensis, as has been observed in other species of Hyalella, appear to be related to their reproductive behavior (Wellborn, 1994; 1995; Wellborn and Cothran, 2007; Castiglioni and Bond-Buckup, 2008b). Males spend more time exposed 
in the environment by choosing a female that they will carry during the pre-copula, which turn them more susceptible to predation, resulting in a population with greater abundance of females. Furthermore, it has been observed that predators, such as fish and Odonata larvae, always prefer to feed the largest specimens of Hyalella, in this case the males, favoring sex ratio for females (Wellborn, 1994). In amphipods, female-biased sex ratios can also be related to variations in temperature, type of vegetation, growth rates, maturity, mortality, longevity, habitat fragmentation, occupation of different microhabitats, food availability and presence of parasites (Wilson and Pianka, 1963; Strong, 1972; Wenner, 1972; Wildish, 1979; Moore, 1981; Powell and Moore, 1991).

Predominance of females in intermediate size class of body size and males in the larger size classes, framed the population of $H$. bonariensis in the anomalous pattern described by Wenner (1972). This result may be related to the greater investment in reproduction by females (Cardoso and Veloso, 1996), as also observed in other species of Hyalella from Brazil (Castiglioni and Bond-Buckup, 2007). Other reason could be the fact that female amphipods incubate the eggs in the marsupium (Borowsky, 1991), and often even juveniles, developing a parental care behavior, which results in a molt prolongation, limiting their growth (Thiel, 2003).

In $H$. bonariensis, the presence of couples in precopula and ovigerous females was recorded throughout the year, but more often in winter, in a way that, consequently, juveniles were also found in greater frequency in winter and spring. Similarly, H. castroi and $H$. pleoacuta, which occur in the highland region of state of Rio Grande do Sul, also reproduce with higher intensity in winter (Castiglioni and Bond-Buckup, 2008a), a pattern also observed in Gammarus duebeni Lilljeborg, 1951, Gammarus oceanicus Segerstrale, 1947, Gammarus salinus Spooner, 1947 (Kolding and Fenchel, 1981) and Corophium multisetosum (see Cunha et al., 2000). Differently from the Brazilian species of Hyalella, H. azteca, a North American species, has a reproduction peak in summer, which could be influenced by temperature (Cooper, 1965; Strong, 1972; Kruschwitz, 1978; March, 1978; Wen, 1992), photoperiod (March, 1977) and oxygen concentration (Nebeker, et al., 1992).
Occurrence of a peak of ovigerous females seems to be related to a greater abundance of aquatic macrophytes on the edge of aquatic environments, because these plants provide food and shelter for Hyalella populations (Castiglioni and Bond-Buckup, 2008b). Hargrave (1970) states that $H$. azteca feeds primarily on algae and bacteria associated with sediment and macrophytes, as well as decomposing animals and plants (Cooper, 1965). At the sampling site of $H$. bonariensis population, a greater abundance of macrophytes was verified in the colder months of the year (D.S. Castiglioni et al., pers. obs.), coinciding with the period of greatest occurrence of ovigerous females. Therefore, future studies about the relation between the presence of aquatic plants and ovigerous females can show the importance of conservation of these microhabitats for the population dynamics of freshwater amphipods.

Juveniles were found throughout the year, probably due to the continuous reproduction of $H$. bonariensis, as mentioned above. Furthermore, juveniles occurred in greater abundance in winter and spring, which may be due to the reproductive peak of the species in winter, resulting in a higher recruitment at this period of the year. Likewise, continuous recruitment was also observed in H. pleocuta and H. castroi (see Castiglioni and Bond-Buckup, 2008b), and other amphipods as Corophium multisetosum (see Cunha et al., 2000), Echinogammarus marinus (Leach, 1815) (Maranhão et al., 2001), E. longisetosus (see Guerao, 2003) and G. chevreuxi (see Subida et al., 2005).

The population of $H$. bonariensis studied in this paper was different when compared to other species of Hyalella, mainly regarding to reproductive peak. Differences in population aspects between $H$. bonariensis and the North American species of Hyalella enhance the urgent necessity in studying the Brazilian species. Then, the creation of environmental quality assessment protocols based in organisms adapted to aquatic ecosystems from Brazil can be a reality. Furthermore, the present study highlights the importance of known the population dynamics of Brazilian species of Hyalella, in order to create a pattern of cultivation in laboratory and, in the future, use these species in ecotoxicology tests. Besides, more studies on the population dynamics of $H$. bonariensis are needed to better understand its life cycle, 
ecology and reproductive aspects, also including other populations from the same species. Later, this species can be used in ecotoxicology testing and evaluation of environmental quality, in order to help the conservation and preservation of freshwater environments in Brazil.

\section{ACKNOWLEDGEMENTS}

This research was funded by Conselho Nacional de Desenvolvimento Científico e Tecnológico - Brasil (CNPq - Process $\mathrm{N}^{\circ}$ 477554/2011-3). DSC and AVO are grateful to the Coordenação de Aperfeiçoamento de Pessoal de Nível Superior (CAPES) and CNPq (Process no 55.2597/2011-2) for the financial support. SGR is also grateful to CAPES for the Ph.D. scholarship.

\section{References}

Adams, J. and Greenwood, P.J. 1983. Why are males bigger than females in pre-copula pairs of Gammarus pulex? Behavioral Ecology and Sociobiology, 13(4): 239-241.

Adams, J.; Greenwood, P.J.; Pollitt, P.R. and Yonow, T. 1985. Loading constraints and sexual size dimorphism in Asellus aquaticus. Behaviour, 92(3/4): 277-287.

Appadoo, C. and Myers, A.A. 2004. Reproductive bionomics and life history traits of three gammaridean amphipods, Cymadusa filosa Savigny, Ampithoe laxipodus Appadoo and Myers and Mallacoota schellenbergi Ledoyer from tropical Indian Ocean (Mauritius). Acta Oecologica, 26(3): 227-238.

Bento, F.M. and L. Buckup. 1999. Subordem Gammaridea. p. 177-188. In: L. Buckup and G. Bond-Buckup (eds), Os Crustáceos do Rio Grande do Sul. Porto Alegre, Ed. Universidade, UFRGS.

Borowsky, B. 1991. Patterns of reproduction of some amphipod crustaceans and insights into the nature of their stimuli. p. 33-66. In: R.T. Bauer and W. Martin (eds), Crustacean Sexual Biology. New York, Columbia University Press.

Brawn, J.D. and Robinson, S.K. 1996. Dynamics may complicate the interpretation of long-term census data. Ecology, 77(1): 3-12.

Bueno, A.A.P.; Rodrigues, S.G. and Araujo, P.B. 2014. O estado da arte do gênero Hyalella Smith, 1874 (Crustacea, Amphipoda, Senticaudata, Hyalellidae) no Brasil. p. 57-88. In: C. Hayashi (ed), Tópicos de atualização em ciências aquáticas, Vol. 1, 1ed. Uberaba: UFMG.

Cardoso, R.S. and Veloso, V.G. 1996. Population biology and secondary production of the sandhopper Pseudorchestoidea brasiliensis (Amphipoda: Talitridae) at Prainha Beach, Brazil. Marine Ecology Progress Series, 142(1-3): 111-119.

Castiglioni, D.S. and Bond-Buckup, G. 2007. Reproductive strategies of two sympatric species of Hyalella Smith, 1874 (Amphipoda, Dogielinotidae) in laboratory conditions. Journal of Natural History, 41(25/28): 1571-1584.

Castiglioni, D.S. and Bond-Buckup, G. 2008a. Ecological traits of two sympatric species of Hyalella Smith, 1874 (Crustacea, Amphipoda, Dogielinotidae) from southern Brazil. Acta Oecologica, 33(1): 36-48.
Castiglioni, D.S. and Bond-Buckup, G. 2008b. Pairing and reproductive success in two sympatric species of Hyalella (Crustacea, Amphipoda, Dogielinotidae) from southern Brazil. Acta Oecologica, 33(1): 49-55.

Castiglioni, D.S. and Bond-Buckup, G. 2009. Egg production of two sympatric species of Hyalella Smith, 1874 (Crustacea, Amphipoda, Dogielinotidae) in aquaculture ponds in southern Brazil. Journal of Natural History, 43(21-22): 1273-1289.

Castiglioni, D.S.; Garcia-Schroeder, D.; Barcelos, D.F. and BondBuckup, G. 2007. Intermolt duration and postembryonic growth of two sympatric species of Hyalella (Amphipoda, Dogielinotidae) in laboratory conditions. Nauplius, 15(2): 57-64.

Colla, M.F. and César, I.I. 2015. A new species of Hyalella (Crustacea, Amphipoda, Dogielinotidae) from the Atlantic Forest of Misiones, Argentina. Zookeys, 481: 25-38.

Cooper, W.E. 1965. Dynamics and production of a natural population of a freshwater amphipod Hyalella azteca. Ecological Monographs, 35(4): 377-394.

Cunha, M.R.; Sorbe, J.C. and Moreira, M.H. 2000. The amphipod Corophium multisetosum (Corophiidae) in Ria de Aveiro (NW Portugal). I. Life history and aspects of reproductive biology. Marine Biology, 137(4): 637-650.

Curi, P.R. and Moraes, R.V. 1981. Associação, homogeneidade e contrastes entre proporções em tabelas contendo distribuições multinomiais. Ciência e Cultura, 33(5): 712-722.

Díaz, H. and Conde, J.E., 1989. Population dynamics and life of mangrove crab Aratus pisonii (Brachyura, Grapsidae) in a marine environment. Bulletin of Marine Science, 45(1): $148-163$.

Ding, Y.; Weston, D.P.; You, J.; Rothert, A.K. and Lydy, M.J. 2011. Toxicity of sediment-associated pesticides to Chironomus dilutus and Hyalella azteca. Archives of Environmental Contamination and Toxicology, 61(1): 83-92.

Duan, Y.; Guttman, S.I. and Oris, J.T. 1997. Genetic differentiation among laboratory populations of Hyalella azteca: implications for toxicology. Environmental Toxicology and Chemistry, 16(4): 691-695.

Emmerson, W.D. 1994. Seasonal breeding cycles and sex ratios of eight species of crabs from Mgazana, a mangrove estuary in Transkei, southern Africa. Journal of Crustacean Biology, 14(3): 568-578.

Gonçalves, S.C.; Marques, J.C.; Pardal, M.A.; Bouslama, F.M.; Gtari, M. and Charfi-Cheikhrouha, F. 2003. Comparison of the biology, dynamics, and secondary production of Talorchestia brito (Amphipoda, Talitridae) in Atlantic (Portugal) and Mediterranean (Tunisia) populations. Estuarine, Coastal and Shelf Science, 58(4): 901-916.

Guerao, G. 2003. Some observations on the life history of the freshwater amphipod Echinogammarus longisetosus Pinkster, 1973 (Gammaridea) from Catalonia (Spain, N Iberia peninsula). Animal Biodiversity and Conservation, 26(1): 31-39.

Gust, K.A. 2006. Joint toxicity of cadmium and phenanthrene in the freshwater amphipod Hyalella azteca. Archives of Enrironmental Contamination and Toxicology, 50(1): 7-13.

Hargrave, B.T. 1970. The utilization of benthic microflora by Hyalella azteca (Amphipoda). Journal of Animal Ecology, 39(2): 427-437. 
Hartnoll, R.G. 1982. Growth. p. 111-196. In: D.E. Bliss and L.G. Abele (eds), The biology of Crustacea: embryology, morphology and genetics, Vol. 2. New York, Academic Press.

Hutchinson, G.E. 1981. Introducción a la ecologia de poblaciones. Barcelona, Editora Blume, 492p.

Kevrekidis, T. 2004. Population dynamics, growth and reproduction of Corophium insidiosum (Crustacea: Amphipoda) at low salinities in Monolimni lagoon (Evros Delta, north Aegean Sea). Hydrobiologia, 522(1): 117-132.

Kevrekidis, T. 2005. Life history, aspects of reproductive biology and production of Corophium orientale (Crustacea: Amphipoda) in Monolimni lagoon (Evros Delta, north Aegean Sea). Hydrobiologia, 537(1): 53-70.

Kolding, S. and Fenchel, T.M. 1981. Patterns of reproduction in different populations of five species of the amphipod genus Gammarus. Oikos, 37(2): 167-172.

Kruschwitz, L.G. 1978. Environmental factors controlling reproduction of the amphipod Hyalella azteca. Proceedings of the Oklahoma Academy of Science, 58: 16-21.

Low, B.S. 1978. Environmental uncertainty and parental strategies of marsupials and placentals. American Naturalist, 112(983): 319-335.

Maranhão, P.; Bengala, N.; Pardal, M. and Marques, J.C. 2001. The influence of environmental factors on the population dynamics, reproductive biology and productivity of Echinogammarus marinus Leach (Amphipoda, Gammaridae) in the Mondego estuary (Portugal). Acta Oecologica, 22(3): 139-152.

March, B.G.E. 1977. The effects of photoperiod and temperature on the induction and termination of reproductive resting stage in the freshwater amphipod Hyalella azteca (Saussure). Canadian Journal of Zoology, 55(10): 1595-1600.

March, B.G.E. 1978. The effects of constant and variable temperatures on the size, growth, and reproduction of the freshwater amphipod Hyalella azteca (Saussure). Canadian Journal of Zoology, 56(8): 1801-1806.

Markus, R. 1971. Elementos de estatística aplicada. Porto Alegre, Faculdade de Agronomia e Veterinária da UFRGS: Centro Acadêmico Leopoldo Cortez, 329 p.

Marrón-Becerra, A.; Hermoso-Salazar, M. and Solís-Weiss, V. 2014. Hyalella cenotensis, a new species of Hyalellidae (Crustacea, Amphipoda) from the Yucatán Peninsula, Mexico. Zootaxa, 3811(2): 262-270.

Moore, P.G. 1981. The life histories of the amphipods Lembos websteri Bate and Corophium bonnellii Milne Edwards in kelp holdfasts. Journal of Experimental Marine Biology and Ecology, 49(1): 1-50.

Morris, J.M.; Collyard, S.A. and Meyer, J.S. 2003. Effects of chronic copper exposure on the nutritional composition of Hyalella azteca. Aquatic Toxicology, 63(2): 197-206.

Muskó, I.B. 1992. Life history of Corophium curvispinum G. O. Sars (Crustacea, Amphipoda) living on macrophytes in Lake Balaton. Hydrobiologia, 243/244: 197-202.

Nebeker, A.V.; Onjukka, S.T.; Stevens, D.G.; Chapman, G.A. and Dominguez, S.E. 1992. Effects of low dissolved oxygen on survival, growth and reproduction of Daphnia, Hyalella and Gammarus. Environmental Toxicology and Chemistry, 11(3): 373-379.
Neuparth, T.; Costa, F.O. and Costa, M.H. 2002. Effects of temperature and salinity on life history of the marine amphipod Gammarus locusta. Implications for ecotoxicological testing. Ecotoxicology, 11(1): 55-67.

Pickard, D.P. and Benke, A.C. 1996. Production dynamics of Hyalella azteca (Amphipoda) among different habitats in a small wetland in the southeastern USA. Journal of the North American Benthological Society, 15(4): 537-550.

Powell, R. and Moore, P.G. 1991. The breeding cycles of females of seven species of amphipod (Crustacea) from the Clyde Sea area. Journal of Natural History, 25(2): 435-479.

Rinderhagen, M.; Ritterhoff, J. and Zauke, G.P. 2000. Crustaceans as bioindicators. In: A. Geerhardt (ed), Biomonitoring of Polluted Water - Reviews on Actual Topics. Trans Tech Publications - Scitech Publications, Environmental Research Forum, 9: 161-194.

Rodrigues, S.G.; Bueno, A.A.P. and Ferreira, R.L. 2014. A new troglobiotic species of Hyalella (Crustacea, Amphipoda, Hyalellidae) with a taxonomic tree for the Brazilian species. Zootaxa, 3815(2): 200-214.

Strong, D.R. 1972. Life history variation among populations of an amphipod (Hyalella azteca). Ecology, 53(6): 1103-1111.

Subida, M.D.; Cunha, M.R. and Moreira, M.H. 2005. Life history, reproduction, and production of Gammarus chevreuxi (Amphipoda: Gammaridea) in the Ria de Aveiro, northwestern Portugal. Journal of the North American Benthological Society, 4(1): 82-100.

Swanson, G.A. 1984. Dissemination of amphipods by waterfowl. The Journal of Wildlife Management, 48(3): 988-991.

Thiel, M. 1999. Extended parental care behaviour in crustaceans da comparative overview. p. 211-226. In: J.C. von Vaupel Klein and F.R. Schram (eds), Crustacean Issues 12: The Biodiversity Crisis and Crustacea. Rotterdam, A.A. Balkema, 848 p.

Thiel, M. 2003. Extended parental care in crustaceans: an update. Revista Chilena de Historia Natural, 76(2): 205-218.

Wellborn, G.A. 1994. Size-biased predation and prey life histories: a comparative study of freshwater amphipod populations. Ecology, 75(7): 2104-2117.

Wellborn, G.A. 1995. Determinants of reproductive success in freshwater amphipod species that experience different mortality regimes. Animal Behavior, 50(2): 353-363.

Wellborn, G.A. 2002. Trade-off between competitive ability and antipredator adaptation in a freshwater amphipod species complex. Ecology, 83(1): 129-136.

Wellborn, G.A. and Cothran, R.D. 2007. Niche diversity in crustacean cryptic species: complementarity in spatial distribution and predation risk. Oecologia, 154(1): 175-183.

Wellborn, G.A.; Cothran, R. and Bartholf, S. 2005. Life history and allozyme diversification in regional ecomorphs of the Hyalella azteca (Crustacea: Amphipoda) species complex. Biological Journal of the Linnean Society, 84(2): 161-175.

Wen, Y.H. 1992. Life history and production of Hyalella azteca (Crustacea: Amphipoda) in a hypereutrophic prairie pond in southern Alberta. Canadian Journal of Zoology, 70(7): 1417-1424.

Wenner, A.M. 1972. Sex-ratio as a function of size in marine Crustacea. American Naturalist, 106(949): 321-350. 
Wilcoxen, S.E.; Meier, P.G. and Landrum, P.F. 2003. The toxicity of fluoranthene to Hyalella azteca in sediment and water-only exposures under varying ligth spectra. Ecotoxicology and Environmental Safety, 54: 105-117.

Wildish, D.J. 1979. Reproductive consequences of the terrestrial habit in Orchestia (Crustacea: Amphipoda). International Journal of Invertebrate Reproduction, 1(1): 9-20.
Wilson, M.F. and Pianka, E.R. 1963. Sexual selection, sex ratio and mating system. American Naturalist, 97(897): 405-407.

Zar, J.H. 1996. Biostatistical Analysis. Upper Saddle River, Prentice Hall, 941 p.

Zielinski, D. 1998. Life cycle and altitude range of Gammarus leopoliensis Jazdzewski \& Konopacka, 1989 (Amphipoda) in south-eastern Poland. Crustaceana, 71(2): 129-143. 